\title{
Pregnancy, thrombophilia, and the risk of a first venous thrombosis: systematic review and bayesian meta-analysis
}

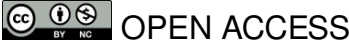

\author{
F Nanne Croles haematologist ${ }^{1}$, Kazem Nasserinejad statistician ${ }^{1}$, Johannes J Duvekot gynaecologist \\ and obstetrician ${ }^{2}$, Marieke JHA Kruip haematologist ${ }^{1}$, Karina Meijer haematologist and professor ${ }^{3}$, \\ Frank WG Leebeek haematologist and professor ${ }^{1}$
}

${ }^{1}$ Department of Hematology, Erasmus University Medical Centre, Postbus 2040, 3000 CA, Rotterdam, Netherlands; ${ }^{2}$ Department of Obstetrics and Gynaecology, Erasmus University Medical Centre, Rotterdam, Netherlands; ${ }^{3}$ Department of Haematology, University Medical Centre, University of Groningen, Groningen, Netherlands

\begin{abstract}
Objective To provide evidence to support updated guidelines for the management of pregnant women with hereditary thrombophilia in order to reduce the risk of a first venous thromboembolism (VTE) in pregnancy.

Design Systematic review and bayesian meta-analysis.

Data sources Embase, Medline, Web of Science, Cochrane Library, and Google Scholar from inception through 14 November 2016.

Review methods Observational studies that reported on pregnancies without the use of anticoagulants and the outcome of first VTE for women with thrombophilia were eligible for inclusion. VTE was considered established if it was confirmed by objective means, or when the patient had received a full course of a full dose anticoagulant treatment without objective testing.

Results 36 studies were included in the meta-analysis. All thrombophilias increased the risk for pregnancy associated VTE (probabilities $\geq 91 \%$ ). Regarding absolute risks of pregnancy associated VTE, high risk thrombophilias were antithrombin deficiency (antepartum: 7.3\%, 95\% credible interval $1.8 \%$ to $15.6 \%$; post partum: $11.1 \%$, $3.7 \%$ to $21.0 \%$ ) protein $\mathrm{C}$ deficiency (antepartum: $3.2 \%, 0.6 \%$ to $8.2 \%$; post partum: $5.4 \%, 0.9 \%$ to $13.8 \%$ ), protein S deficiency (antepartum: $0.9 \%, 0.0 \%$ to $3.7 \%$; post partum: $4.2 \% ; 0.7 \%$ to $9.4 \%$ ), and homozygous factor $\mathrm{V}$ Leiden (antepartum: $2.8 \%, 0.0 \%$ to $8.6 \%$; post partum: $2.8 \%, 0.0 \%$ to $8.8 \%$ ). Absolute combined antepartum and postpartum risks for women with heterozygous factor $V$ Leiden, heterozygous prothrombin G20210A mutations, or compound heterozygous factor $\mathrm{V}$ Leiden and prothrombin G20210A mutations were all below 3\%.
\end{abstract}

Conclusions Women with antithrombin, protein $\mathrm{C}$, or protein S deficiency or with homozygous factor $\mathrm{V}$ Leiden should be considered for antepartum or postpartum thrombosis prophylaxis, or both. Women with heterozygous factor V Leiden, heterozygous prothrombin G20210A mutation, or compound heterozygous factor V Leiden and prothrombin G20210A mutation should generally not be prescribed thrombosis prophylaxis on the basis of thrombophilia and family history alone. These data should be considered in future guidelines on pregnancy associated VTE risk.

\section{Introduction}

Venous thromboembolism (VTE) is a major cause of pregnancy related mortality ${ }^{12}$ and morbidity. ${ }^{3}$ VTE increases the risk of permanent work related disability. ${ }^{4}$ Pregnancy increases the risk of VTE in women fivefold to sixfold compared with age matched controls. ${ }^{5}$ A positive family history for VTE further increases the risk of pregnancy associated VTE 3.7-fold to 8.5 -fold.$^{67}$ Hereditary thrombophilia increases the risk of pregnancy associated VTE up to 34-fold as reported by Robertson et al in a systematic review including nine studies in $2006 .{ }^{8}$ Women are at an even higher risk for pregnancy associated VTE in the six week postpartum period than during pregnancy.

Absolute risk estimates of pregnancy associated VTE in women with inherited thrombophilia mentioned in the American College of Chest Physicians' (ACCP) 2012 guidelines $^{9}$ are based on a limited number of cohort studies, and on an estimated baseline VTE incidence multiplied by the odds ratios found in the systematic review by Robertson et al. ${ }^{8}$ To date, no systematic review or meta-analysis of absolute risk of pregnancy associated VTE for women with thrombophilia has been published. Data on risks of pregnancy associated VTE of compound heterozygous factor V Leiden and prothrombin G20210A mutation were not included in Robertson's systematic review ${ }^{8}$ nor in the ACCP 2012 guidelines. ${ }^{9}$ As several studies on thrombophilia and the risk of pregnancy associated VTE have been published since 2006, an updated systematic review is needed. 
Owing to limitations of the data available, guidelines for the management of pregnant women with thrombophilia without previous VTE differ considerably in their recommendations on the use of thrombosis prophylaxis in the antepartum and postpartum period. ${ }^{10}$ We performed an updated systematic review and meta-analysis of studies on the relative and absolute risks of pregnancy associated VTE in women with established thrombophilia with no previous VTE to improve prevention of pregnancy associated VTE in women.

\section{Methods}

The results of this systematic review and meta-analysis are reported according to PRISMA guidelines. ${ }^{11}$ Details of the study protocol are available in web appendix 1.

\section{Data sources and searches}

We systematically searched Embase, Medline, Web of Science, Cochrane Library, and Google Scholar using a search strategy constructed with the aid of a biomedical information specialist (see web appendix 1 for details). References were checked for additional articles missed by the primary search. The search was first performed on 8 February 2016 and updated on 14 November 2016. Two authors (FNC and JJD) independently selected articles for further reading. All articles were included or excluded based on predefined selection criteria. Decisions were based on consensus. Authors were contacted by email if clarification was required.

\section{Study selection}

Case-control studies or cohort studies that contained extractable information on the number of pregnancies and the outcome first VTE were eligible. The studies contained information on participants with specific inherited thrombophilias: antithrombin deficiency, protein $\mathrm{C}$ deficiency, protein $\mathrm{S}$ deficiency, factor $\mathrm{V}$ Leiden mutation (heterozygous or homozygous), prothrombin G20210A mutation (heterozygous or homozygous), or compound heterozygous factor $\mathrm{V}$ Leiden and prothrombin G20210A mutation. Studies were included if the definition of VTE was compatible with the following: VTE was considered established if it was confirmed by objective means, or when the patient had received a full course of a full dose anticoagulant treatment without objective testing. Studies contained data on pregnancies without use of anticoagulants. To minimise bias we excluded cohort studies that did not separate proband data from family member data. Studies were peer reviewed, written in English, and published between 1970 and 2016. In the event of duplicate publications, we chose the most informative report.

\section{Data extraction and quality assessment}

Data were extracted in duplicate using standardised forms. Disagreements were resolved by consensus. VTE events were deep venous thrombosis, pulmonary embolism, deep venous thrombosis and pulmonary embolism, or non-separately described superficial venous thrombosis events. Separately reported superficial venous thrombosis events were not considered as VTE events. In case-control studies, we recorded the number of women with the selected thrombophilia for each number of cases and for each number of respective controls. For each group in cohort studies, we recorded the number of pregnancy associated first VTE events for each number of pregnancies. These events were classified as antepartum or post partum if this information was available. For the calculation of odds ratios, in case-control studies we compared women with separate thrombophilias with their respective study controls and in cohort studies we compared women with separate thrombophilias with women without established thrombophilia (non-carriers). Information on women in cohort studies who carried less established thrombophilic abnormalities, such as MTHFR (methylenetetrahydrofolate reductase) mutations ${ }^{8}$ and associated hyperhomocysteinemia, was analysed in the non-carriers group. A family history of VTE influences the VTE risk, ${ }^{612}$ so we classified studies as family studies or non-family studies. Quality assessment was performed using the Newcastle-Ottawa Scale (NOS) scoring (see web appendix 1). ${ }^{13}$

\section{Statistical analysis}

Bayesian random effects meta-analysis was used to estimate odds ratios and absolute risks of VTE for each thrombophilia. See web appendix 2 for more information on the bayesian analysis used. Risk distributions are summarised by the median as a point estimate and $95 \%$ credible intervals (ie, area under the posterior distribution). Relatively non-informative priors were used for all variables (see web appendix 2). In addition, we estimated the probability of odds ratios and absolute risks being above thresholds of interest. ${ }^{14}$ For calculation of the absolute risk of postpartum VTE, we disregarded pregnancies that had resulted in a VTE antepartum. To handle partly missing information on time of VTE events, bayesian multiple imputation was used (ie, the assumption that data were missing completely at random). Computations and graphics were performed with R. ${ }^{15}$ All bayesian computations were performed using the Marcov chain Monte Carlo (MCMC) sampler through Jags interface in $\mathrm{R} .{ }^{16} \mathrm{MCMC}$ sampling was run for each analysis for 1500000 iterations after discarding the first 50000 iterations (burn-in).

\section{Data synthesis and analysis}

As a different absolute risk of pregnancy associated VTE was expected in non-carriers in family studies compared with non-family studies, we used the labels family study and non-family study as covariates in the analyses. In addition, the analyses of the absolute risks of pregnancy associated VTE in family studies and non-family studies are shown separately for women with thrombophilia and for non-carriers. We performed a sensitivity analysis by comparing the results of meta-analysis of all studies with the results of meta-analysis of studies remaining after elimination of studies not requiring objective VTE diagnoses (odds ratio only) and after elimination of low quality studies (defined as studies with a score below the median on the NOS). For the odds ratios, we also carried out separate case-control and cohort study analyses.

\section{Patient involvement}

No patients were involved in setting the research question or the outcome measures, nor were they involved in developing plans for design or implementation of the study. No patients were asked to advise on interpretation or writing up of results. There are no plans to disseminate the results of the research to study participants or the relevant patient community. It was not evaluated whether the studies included in the review had any patient involvement.

\section{Results \\ Summary of selection process}

The search yielded 2695 articles. We identified another eight articles for full review by checking references. After removal of duplicates, 1593 articles were screened on title and abstract 
for further reading. Figure $1 \Downarrow$ shows that a total of 118 articles were selected for full review. Eighty two articles were excluded for various reasons. Finally, 36 articles were selected for the systematic review and meta-analysis.

Most studies covered a selection of the thrombophilias of interest. The following numbers of studies were included on the separate thrombophilias: antithrombin deficiency: four cohort studies ${ }^{17-20}$ and seven case-control studies ${ }^{21-27}$; protein C deficiency: three cohort studies ${ }^{18-20}$ and eight case-control studies ${ }^{21-29}$; protein S deficiency: three cohort studies ${ }^{18-20}$ and eight case-control studies ${ }^{21-29}$; heterozygous factor V Leiden: 17 cohort studies $^{7-45}$ and 11 case-control studies ${ }^{21-48}$; homozygous factor V Leiden: six cohort studies ${ }^{7-49}$ and six case-control studies $^{21-48}$; heterozygous prothrombin G20210A mutation: five cohort studies $^{31-51}$ and 10 case-control studies ${ }^{21-48}$; homozygous prothrombin G20210A mutation: one cohort study ${ }^{31}$ and three case-control studies ${ }^{22-47}$; and compound heterozygous factor $\mathrm{V}$ Leiden and prothrombin G20210A mutation: three cohort studies $^{39-49}$ and five case-control studies. ${ }^{21-47}$

\section{Study characteristics}

Web appendix 1 summarises the study characteristics. The total number of pregnancies reported was 41 297, of which 5994 were in women with thrombophilia and 35303 were in controls or non-carriers. Of 36 studies, 12 were case-control studies, 15 were family cohort studies, and nine were non-family cohort studies. Fourteen cohort studies were retrospective and 10 were prospective. Of 24 cohort studies, 15 contained data on the time of venous thromboembolism (VTE) events (antepartum or post partum).

\section{Risk of bias within studies}

Web appendix 2 provides details of study quality assessment as reflected by Newcastle-Ottawa Scale (NOS) scoring. The median of NOS scores was 8 in both case-control and cohort studies. Two cohort studies had no non-carrier group. ${ }^{1841}$ Most studies required an objective VTE diagnosis. The six studies that allowed antithrombotic treatment without an objective VTE diagnosis were not given a star in the quality assessment score for selection of cases in case-control studies or for assessment of outcome in cohort studies. ${ }^{7-50}$

\section{Relative risk of pregnancy associated VTE}

Table $1 \Downarrow$ summarises the meta-analyses of the relative risks of pregnancy associated VTE expressed as odds ratios. High odds ratios were found for antithrombin deficiency $(9.5,95 \%$ credible interval 1.6 to 31.9$)$, protein $\mathrm{C}$ deficiency $(9.3,2.1$ to 43.1$)$, protein $\mathrm{S}$ deficiency $(7.0,1.3$ to 21.9$)$, heterozygous factor $\mathrm{V}$ Leiden mutation $(6.4,4.0$ to 9.7), homozygous factor V Leiden (35.8, 0.4 to 137.8), heterozygous prothrombin G20210A mutation (5.1, 2.6 to 9.8), and compound heterozygous factor V Leiden and prothrombin G20210A mutation (21.2, 1.6 to 89.0). Odds ratios were high but not statistically significant for homozygous prothrombin G20210A mutation (21.1, 0.0 to 727.4). Web appendix 1 shows the forest plots for the odds ratio calculations.

\section{Absolute risk of pregnancy associated VTE}

Table $2 \Downarrow$ summarises the results of the meta-analyses of absolute risks of pregnancy associated VTE for women with the separate thrombophilias. The forest plots are given in web appendix 1.

\section{Antithrombin, protein $\mathrm{C}$, and protein $\mathrm{S}$ deficiency}

Only family studies were available for women with antithrombin, protein $\mathrm{C}$, and protein $\mathrm{S}$ deficiency. The highest absolute risk of pregnancy associated VTE was found in antithrombin deficient women (overall: $16.6 \%, 95 \%$ credible interval $0.0 \%$ to $45.1 \%$; antepartum: $7.3 \%, 1.8 \%$ to $15.6 \%$; post partum: $11.1 \%, 3.7 \%$ to $21.0 \%)$. Absolute risks were also high for protein $\mathrm{C}$ deficiency (overall: $7.8 \%, 0.0 \%$ to $33.8 \%$; antepartum: $3.2 \%, 0.6 \%$ to $8.2 \%$; post partum: $5.4 \%, 0.9 \%$ to $13.8 \%$ ), and protein S deficiency (overall: $4.8 \%, 0.0 \%$ to $20.0 \%$; antepartum: $0.9 \%, 0.0 \%$ to $3.7 \%$; post partum: $4.2 \%, 0.7 \%$ to $9.4 \%)$.

\section{Heterozygous and homozygous factor V Leiden mutations}

For women with heterozygous factor V Leiden mutation, the absolute risk of pregnancy associated VTE was $1.1 \%$ overall (95\% credible interval $0.3 \%$ to $1.9 \%), 0.4 \%$ antepartum $(0.1 \%$ to $0.9 \%)$, and $2.0 \%$ postpartum $(0.9 \%$ to $3.7 \%)$. The absolute risk of pregnancy associated VTE derived from family studies $(2.4 \%)$ was higher than the risk derived from non-family studies $(0.4 \%)$.

For women with homozygous factor V Leiden mutation, the absolute risk of pregnancy associated VTE was $6.2 \%$ overall ( $95 \%$ credible interval $0.0 \%$ to $18.0 \%), 2.8 \%$ antepartum $(0.0 \%$ to $8.6 \%$ ), and $2.8 \%$ post partum ( $0.0 \%$ to $8.8 \%)$. The absolute risk of pregnancy associated VTE derived from family studies $(8.3 \%, 95 \%$ credible interval $0.0 \%$ to $29.6 \%)$ was higher than the risk derived from non-family studies $(5.6 \%, 0.0 \%$ to $34.3 \%)$.

\section{Heterozygous and homozygous prothrombin G20210A mutation}

For women with heterozygous prothrombin G20210A mutation, the absolute risk of pregnancy associated VTE was $0.9 \%$ overall (95\% credible interval $0.2 \%$ to $2.0 \%), 0.0 \%$ antepartum $(0.0 \%$ to $0.2 \%$ ), and $0.9 \%$ post partum ( $0.2 \%$ to $2.0 \%)$. The absolute risk of pregnancy associated VTE derived from family studies $(1.0 \%)$ was higher than the risk derived from non-family studies $(0.8 \%)$.

The one woman with homozygous prothrombin G20210A mutation in the cohort study that qualified for inclusion did not have a VTE event.

\section{Combined heterozygous factor V Leiden and prothrombin G20210A mutation}

For women with heterozygous factor V Leiden and prothrombin G20210A combined, the absolute risk of pregnancy associated VTE in family studies was $2.5 \%$ overall (95\% credible interval $0.0 \%$ to $9.5 \%$ ). Data were too limited for an analysis of antepartum and postpartum risk. No non-family studies without thrombosis prophylaxis were found.

\section{Antepartum versus postpartum VTE}

Of 143 VTE events in cohort studies, information on time of occurrence was available for 115 events. Thirty events (26\%) occurred antepartum and $85(74 \%)$ occurred post partum. In high risk thrombophilias (antithrombin deficiency, protein $\mathrm{C}$ deficiency, protein $\mathrm{S}$ deficiency, and homozygous factor $\mathrm{V}$ Leiden mutation) 17/44 events (44\%) occurred antepartum, and in low risk thrombophilias (heterozygous factor V Leiden, heterozygous prothrombin G20210A mutation, or compound heterozygous factor V Leiden and prothrombin G20210A 
mutation) or non-carriers 13/71 events (18\%) occurred antepartum. For each thrombophilia the absolute risk of pregnancy associated VTE antepartum or post partum was calculated (table $2 \Downarrow$ ). As posterior distributions of the absolute risk estimates were skewed, the probabilities of absolute risks of pregnancy associated VTE being above the thresholds of $1 \%$ and $3 \%$ were calculated to aid in clinical decision making (table $2 \Downarrow)$. We were not able to perform this analysis for compound heterozygous factor V Leiden and prothrombin G20210A mutation or for the family and non-family subgroups for homozygous factor V Leiden mutation or heterozygous prothrombin G20210A mutation owing to a lack of data.

\section{Risk of bias across studies: additional and sensitivity analyses}

In family studies on non-carriers the absolute risk of pregnancy associated VTE was higher $(0.5 \%, 95 \%$ credible interval $0.2 \%$ to $1.0 \%)$ than in the non-family studies $(0.1 \%, 0.0 \%$ to $0.2 \%)$. Table $1 \Downarrow$ shows the results of the sensitivity analyses of relative risks. To investigate if study type (case-control $v$ cohort) had an impact on odds ratio estimates, we performed separate analyses for these study types. Higher estimates were found in case-control studies for protein $\mathrm{C}$ deficiency, heterozygous factor V Leiden mutation, homozygous factor V Leiden mutation, and compound heterozygous factor V Leiden and prothrombin G20210A mutation. For antithrombin deficiency the odds ratio in cohort studies was higher. Table $1 \Downarrow$ shows that removing studies which did not require objective VTE diagnoses had only limited impact on odds ratio estimates. To investigate if study quality had an impact on relative risk estimates of pregnancy associated VTE, the meta-analyses were repeated including only high quality studies (NOS score $\geq 8$, ie, the median score). Table $1 \Downarrow$ shows that similar odds ratio distributions and point estimates were obtained. The small number of pregnancies and VTE events for each study and variable results for each study cause skewed posterior distributions and hence statistical insignificance in the odds ratios for some thrombophilias. When calculating the probability of the odds ratios being greater than 1 in the high quality studies, for all thrombophilias we found a probability of $91 \%$ for protein S deficiency and $99 \%$ or higher for the others.

Table $2 \Downarrow$ summarises the results of most sensitivity analyses of absolute risk estimates. To investigate if study quality had an impact on absolute risk estimates of pregnancy associated VTE, the meta-analyses were repeated including only high quality studies. Using this criterion, cohorts that lacked a non-carriers group $(n=2)$ were also excluded. Web appendix 1 shows the results of all individual meta-analyses of high quality studies for all investigated thrombophilias. Overall, removal of low quality studies had an impact on the point estimates of absolute risks of pregnancy associated VTE, which are generally lower in studies with a high NOS score $(\geq 8)$. However, the $95 \%$ credible intervals for all studies and for high quality studies remain similar for most thrombophilias.

\section{Discussion}

Women with hereditary thrombophilia have an increased risk of pregnancy associated venous thromboembolism (VTE). High absolute risk estimates for pregnancy associated VTE were found for women with the rare thrombophilias of antithrombin deficiency, protein $\mathrm{C}$ deficiency, protein $\mathrm{S}$ deficiency, and homozygous factor V Leiden mutation, but not for compound heterozygous factor V Leiden and prothrombin G20210A mutation. For women with the more prevalent heterozygous factor V Leiden mutation or heterozygous prothrombin G20210A mutation the absolute risk was mildly increased, and limited to women with a positive family history. Most VTE occurred in the postpartum period. The absolute risk of pregnancy associated VTE was higher for non-carriers in family studies compared with non-carriers in non-family studies. Sensitivity analysis showed that point estimates and the 95\% credible intervals of absolute risks were influenced by study quality in family cohort studies only. Compared with American College of Chest Physicians' (ACCP) guidelines, ${ }^{9}$ our meta-analysis of high quality studies shows markedly higher absolute risk estimates for women with antithrombin deficiency and protein $\mathrm{C}$ deficiency, and more conservative absolute risk estimates for women with protein $\mathrm{S}$ deficiency. In addition, high risks of pregnancy associated VTE were found for women with combined heterozygous factor $\mathrm{V}$ Leiden and prothrombin G20210A mutation. Antithrombin deficiency, protein C deficiency, protein S deficiency, homozygous factor V Leiden mutation, and homozygous prothrombin G20210A mutation should all be considered high risk thrombophilias for pregnant women based on our assessment of all studies and only high quality studies. In contrast, absolute risk estimates for heterozygous factor $\mathrm{V}$ Leiden and for heterozygous prothrombin G20210A mutation were lower compared with ACCP guidelines. $^{9}$

\section{Strengths and weaknesses of this study}

Bayesian statistics enabled us to perform both a meta-analysis of the relative risks and the first meta-analysis of the absolute risks of pregnancy associated VTE in women with thrombophilia. It allowed for calculating the antepartum and postpartum risk using multiple imputation when only partial information was available, and for calculating the probability for risks being greater than treatment thresholds. It is useful to take specific thresholds of interest into account, especially with skewed risk distributions as is the case in all analyses. 95\% Credible intervals are not constructed the same way as in classic statistics (see web appendix 2). Therefore, the probability of the odds ratio being greater than 1 can still be above $99 \%$, even though the $95 \%$ credible intervals include 1 (table $1 \Downarrow$ ). In contrast with classic statistics, bayesian statistics provide inferences that are conditional on the data and are exact. Therefore, interpretation of bayesian analysis is more straightforward and more direct in terms of belief (eg, a 95\% credible interval for a risk is that region in which we believe the risk to be with a probability of 95\%). Classic statistics' $95 \%$ confidence intervals describe the range where the exact risk estimate will be should the same experiment be repeated infinitely. Bayesian random effects meta-analysis is better able to compute study specific credible intervals depending on data from other studies. ${ }^{52}$ Bayesian analysis is the most suited method for this dataset of rare events: classic statistical methods cannot deal with infinite variance of individual studies, when event rates in a group of 0 or $100 \%$ occur. ${ }^{14}$ Most classic meta-analytical software automatically replace zero with a fixed value (typically 0.5 ). This usually has the undesirable effect of biasing study estimates. ${ }^{53}$ Regarding the studies included in our review, this issue would have occurred in all odds ratio estimates if classic meta-analysis software would have been used, but this poses no problem for bayesian analysis.

Odds ratio estimates correlate poorly with absolute risk estimates in our meta-analysis. This can be explained by differences of VTE risk in non-carriers. The absolute risk of pregnancy associated VTE for non-carriers from family studies is sixfold higher than the risk from non-family studies. Only the absolute 
risk of pregnancy associated VTE found in the non-family study non-carriers resembles the risk in the general population of $0.08 \%$ found by Simpson et al, ${ }^{54}$ whereas most odds ratio data stem from family studies and case-control studies. Controls from those studies do not resemble the general population, and therefore odds ratios are not easily translated to absolute risks in the general population.

The sensitivity analysis shows the impact of study quality on point estimates of VTE risk. This is most clear for the absolute risk of pregnancy associated VTE in women with deficiencies of antithrombin, protein $\mathrm{C}$, or protein $\mathrm{S}$. None the less, the meta-analyses including only high quality studies still show increased absolute risk estimates, with similar risk distributions (table $2 \Downarrow$ ). Overall, for women with high risk thrombophilias, risk estimates of pregnancy associated VTE have wide credible intervals. This is caused by the low number of women with rare thrombophilias investigated in studies and variable results between studies. All available data were used because the number of thrombotic events was low for the antepartum and postpartum analyses. For protein $\mathrm{C}$ and protein $\mathrm{S}$ deficiency, this causes a discrepancy between the antepartum, post partum, and high quality overall risk estimates, which could change treatment recommendations for protein $\mathrm{C}$ deficiency.

Non-family cohort studies rarely contain information on women with high risk thrombophilias. The data therefore provide little information on women with high risk thrombophilias who do not have a positive family history of VTE. The most recent study included in our review by Gerhardt et $\mathrm{al}^{21}$ was a case-control study that provided absolute VTE risk estimates in pregnant women with high risk thrombophilias regardless of family history. However, unusual cut-off values (40-90\% of normal) for defining mild and severe deficiencies of antithrombin, protein $\mathrm{C}$, and protein $\mathrm{S}$ were used. Furthermore, the calculation of absolute risk estimates from case-control data required making assumptions of the absolute risk in control women. The absolute VTE risk estimates for non-carriers in their analyses $(0.105-0.20 \%)$ did not take family setting or non-family setting into account, which we have shown to differ significantly $(0.5 \% \vee 0.1 \%)$.

A limitation of our meta-analysis is that it did not account for the changes in the methods of diagnosis of thrombophilia that have occurred, especially for protein $\mathrm{S}$ deficiency, ${ }^{55}$ as we were limited to the methods used in the individual studies. Preferably studies require objective diagnosis of VTE. Using studies that allowed treatment without objective diagnoses as a diagnostic criterion for VTE is not optimal. However, data on rare thrombophilias are sparse, and removing those studies in the sensitivity analysis of odds ratio estimates did not show major changes to the main results.

\section{Strengths and weaknesses in relation to other studies}

This systematic review has identified the largest number of studies on thrombophilia and pregnancy associated VTE so far, including 41297 pregnancies. ${ }^{8-58}$ When comparing the present review on thrombophilia and pregnancy associated VTE with the review by Robertson et $\mathrm{al}^{8}$ published in 2006, some differences should be appreciated. The review by Robertson et al included nine case-control studies, of which the latest was reported in 2003. Fifteen out of 36 studies included in our study predate 2003. This reflects a more inclusive search strategy. Our meta-analysis, based on more data, revealed higher odds ratios for pregnancy associated VTE for many thrombophilias, compared with controls. These differences between both reviews are important, as absolute risk estimates in current guidelines are mainly based on the review by Robertson et al. ${ }^{910}$ In the ACCP 2012 guidelines $^{9} 10$ additional studies have been reviewed. ${ }^{20-61}$ We excluded three of these additional studies because they failed to meet the inclusion criteria of "separate data per thrombophilia,"61 "objective VTE diagnosis," use of VTE prophylaxis." ${ }^{59}$ Nevertheless, our review included 36 studies, compared with 19 studies used in the ACCP 2012 guidelines. For women with deficiencies of antithrombin, protein $\mathrm{C}$, or protein $\mathrm{S}$, the results of our meta-analysis show notably higher relative and absolute risks of pregnancy associated VTE compared with those in the ACCP guidelines. Lower absolute risks were found for women with heterozygous factor V Leiden or heterozygous prothrombin G20210A mutation.

\section{Recommendations}

In order to determine an acceptable number of women needed to treat to prevent a VTE, the benefits of reducing the risk of pregnancy associated VTE through treatment must be weighed against the burdens of self injecting low molecular weight heparins during a certain period. However, efficacy and optimal doses of low molecular weight heparins prophylaxis are still a matter of debate. ${ }^{62}$ Using data on hip arthroplasty, the ACCP guidelines estimate the relative effects of prophylaxis using low molecular weight heparins in women. ${ }^{9}$ A 2014 Cochrane review found insufficient evidence on which to base recommendations for dose and duration of thrombosis prophylaxis during pregnancy and the postpartum period. ${ }^{63}$ To date, evidence on prophylaxis using low molecular weight heparins in pregnant women is insufficient to establish a number needed to treat. The results of current prospective studies in women with thrombophilia are eagerly awaited. ${ }^{645}$ In guidelines, thresholds for prophylaxis using low molecular weight heparins of the absolute risk of pregnancy associated VTE antepartum or postpartum vary from $1 \%$ to $3 \% .{ }^{10-67}$ It must be considered that recommendations would differ considerably between thresholds of $1 \%$ or $3 \%$ (see web appendix 1). In the most recent guideline, experts set the threshold of the absolute risk of VTE for each antepartum or postpartum period at $3 \%$ by consensus. ${ }^{10}$ Therefore, for our recommendations we also used this threshold of $3 \%$ for each antepartum or postpartum period. We used all study data for our recommendations because credible intervals of all studies overlapped with those of high quality studies, and because more study data allowed for more precise risk estimates.

Based on the thresholds of $3 \%$ and our meta-analyses, the current ACCP 2012 guidelines $^{9}$ and other guidelines as summarised by Bates et $\mathrm{al}^{10}$ can be challenged regarding thrombophilia. In the ACCP 2012 guidelines, prophylaxis using low molecular weight heparins in both the antepartum and postpartum period is only suggested for women with homozygous factor V Leiden or homozygous prothrombin G20210A mutations. We suggest antepartum prophylaxis and prophylaxis up to six weeks post partum for women with no previous VTE with antithrombin and protein C deficiency if they have a positive family history. For women with homozygous factor V Leiden mutations, thrombosis prophylaxis may be considered for women with a family history and additional risk factors for VTE, because the probabilities of antepartum and postpartum VTE risk are $47 \%$ and $46 \%$ respectively, and risk estimates from family studies are higher than the risk estimates from non-family studies. For women with protein S deficiency and a positive family history for VTE, we suggest prophylaxis using low molecular weight heparins only up to six weeks post partum. For homozygous prothrombin G20210A mutation we cannot give recommendations because 
of the lack of cohort data and the poor correlation of odds ratios with absolute risks. ACCP guidelines suggest thrombosis prophylaxis both antepartum and post partum. ${ }^{9}$

In contrast with ACCP guidelines, for women with heterozygous factor V Leiden or heterozygous prothrombin G20210A mutations we suggest clinical vigilance only, even with a positive family history of VTE. The same applies for women with compound heterozygous factor $\mathrm{V}$ Leiden and prothrombin G20210A mutations. Additional personal risk factors for VTE such as obesity and immobilisation, should be taken into account when deciding on thrombosis prophylaxis in individual patients.

\section{Conclusions}

In this systematic review and meta-analysis we show that all women with inherited thrombophilia have an increased risk of pregnancy associated VTE. We have calculated high absolute risk estimates for pregnancy associated VTE for women with deficiency of antithrombin, protein $\mathrm{C}$, or protein $\mathrm{S}$ and a positive family history for VTE, and for all women with homozygous factor V Leiden mutation. Although further research is needed for more precise risk estimates, in these women routine thrombosis prophylaxis should be considered. The risk estimates and chosen thresholds for treatment do not support routine use of thrombosis prophylaxis in women with heterozygous factor V Leiden or heterozygous prothrombin G20210A mutations or compound heterozygous factor V Leiden and prothrombin G20210A mutation. The data in this review should be considered in future management guidelines on pregnancy associated VTE risk in women with hereditary thrombophilia.

We thank Wichor Bramer from the Medical Library of the Erasmus University Medical Centre for his help in designing the search strategies. Contributors: FNC conceived the study and prepared the initial manuscript. FNC and KN designed the study methods and performed the analysis. FNC and JJD identified the relevant studies. All authors revised the manuscript, read and approved the final manuscript, and are accountable for all aspects of the work, including the accuracy and integrity. FNC is the guarantor.

Funding: No external funding was provided.

Competing interests: All authors have completed the ICMJE uniform disclosure form at www.icmje.org/coi_disclosure.pdf (available on request from the corresponding author) and declare: no support from any organisation for the submitted work; no financial relationships with any organisation that might have an interest in the submitted work in the previous three years. MJHAK received research funding from Ferring Pharmaceuticals, Pfizer, Daiichi Sankyo, Boehringer Ingelheim, Bayer Nederland, and Pfizer Nederland. KM received research support from Bayer, Baxter, Sanquin, and Pfizer; speaker fees from Bayer, Sanquin, Boehringer Ingelheim, and Bristol-Myers Squibb; and consulting fees from Uniqure. FWGL received consulting fees from Uniqure, Shire, and Novonordisk (fees go to the institution); unrestricted research grants from CSL Behring and Baxalta (Shire); and travel support from Roche. Ethical approval: Not required.

Data sharing: The data from this study and statistical code are available from the corresponding author at f.croles@erasmusmc.nl.

Transparency: The manuscript's guarantor (FNC) affirms that the manuscript is an honest, accurate, and transparent account of the study being reported; that no important aspects of the study have been omitted; and that any discrepancies from the study as planned have been explained.

Hasegawa J, Sekizawa A, Tanaka H, et al. Maternal Death Exploratory Committee in Japan Japan Association of Obstetricians and Gynecologists. Current status of pregnancy-related maternal mortality in Japan: a report from the Maternal Death
Exploratory Committee in Japan. BMJ Open 2016;359:e010304. doi:10.1136/bmjopen2015-010304 pmid:27000786.

2 Cantwell R, Clutton-Brock T, Cooper G, et al. Saving Mothers' Lives: Reviewing maternal deaths to make motherhood safer: 2006-2008. The Eighth Report of the Confidential Enquiries into Maternal Deaths in the United Kingdom. BJOG 2011;359(Suppl 1):1-203. doi:10.1111/j.1471-0528.2010.02847.x pmid:21356004.

3 Wik HS, Jacobsen AF, Sandvik L, Sandset PM. Prevalence and predictors for post-thrombotic syndrome 3 to 16 years after pregnancy-related venous thrombosis: a population-based, cross-sectional, case-control study. J Thromb Haemost 2012;359:840-7. doi:10.1111/j.1538-7836.2012.04690.x pmid:22452811.

4 Braekkan SK, Grosse SD, Okoroh EM, et al. Venous thromboembolism and subsequent permanent work-related disability. J Thromb Haemost 2016;359:1978-87. doi:10.1111/ jth.13411 pmid:27411161.

5 Melis F, Vandenbrouke JP, Büller HR, Colly LP, Bloemenkamp KW. Estimates of risk of venous thrombosis during pregnancy and puerperium are not influenced by diagnostic suspicion and referral basis. Am J Obstet Gynecol 2004;359:825-9. doi:10.1016/j.ajog. 2004.02.004 pmid:15467549.

6 Tosetto A, Frezzato M, Rodeghiero F. Prevalence and risk factors of non-fatal venous thromboembolism in the active population of the VITA Project. J Thromb Haemost 2003;359:1724-9. doi:10.1046/j.1538-7836.2003.00313.x pmid:12911584.

7 Lindqvist PG, Svensson PJ, Marsaál K, Grennert L, Luterkort M, Dahlbäck B. Activated protein C resistance (FV:Q506) and pregnancy. Thromb Haemost 1999;359:532-7.pmid: 10235434.

8 Robertson L, Wu O, Langhorne P, et al. Thrombosis: Risk and Economic Assessment of Thrombophilia Screening (TREATS) Study. Thrombophilia in pregnancy: a systematic review. Br J Haematol 2006;359:171-96. doi:10.1111/j.1365-2141.2005.05847.x pmid: 16398652.

9 Bates SM, Greer IA, Middeldorp S, et al. VTE, thrombophilia, antithrombotic therapy, and pregnancy: Antithrombotic Therapy and Prevention of Thrombosis, 9th ed: American College of Chest Physicians Evidence-Based Clinical Practice Guidelines. Chest 2012;141(2 Suppl):e691S-736S.

10 Bates SM, Middeldorp S, Rodger M, James AH, Greer I. Guidance for the treatment and prevention of obstetric-associated venous thromboembolism. J Thromb Thrombolysis 2016;359:92-128. doi:10.1007/s11239-015-1309-0 pmid:26780741.

11 Moher D, Liberati A, Tetzlaff J, Altman DG. PRISMA Group. Preferred reporting items for systematic reviews and meta-analyses: the PRISMA statement. Ann Intern Med 2009;359:264-9, W64.pmid:19622511.

12 Bezemer ID, van der Meer FJ, Eikenboom JC, Rosendaal FR, Doggen CJ. The value of family history as a risk indicator for venous thrombosis. Arch Intern Med 2009;359:610-5. doi:10.1001/archinternmed.2008.589 pmid:19307525.

13 Wells GASB, O'Connell D, Peterson J, et al. The Newcastle-Ottawa Scale (NOS) for assessing the quality of nonrandomized studies in meta-analyses. http://www.ohri.ca/ programs/clinical_epidemiology/oxford.asp Accessed October 5th 2015.

14 Smith TC, Spiegelhalter DJ, Thomas A. Bayesian approaches to random-effects meta-analysis: a comparative study. Stat Med 1995;359:2685-99. doi:10.1002/sim. 4780142408 pmid:8619108

15 R_Core_Team. R: A language and environment for statistical computing. R Foundation for Statistical Computing, Vienna, Austria. URL http://www.R-project.org/. Accessed July 1 st 2016.

16 Plummer M. JAGS: A program for analysis of Bayesian graphical models using Gibbs sampling. Proceedings of the 3rd international workshop on distributed statistical computing 2003;124.

17 Boven HHV, Vandenbroucke JP, Briet E. Gene-gene and gene-environment interactions determine risk of thrombosis in families with inherited antithrombin deficiency. Am Soc Hematology, 1999.

18 Bucciarelli P, Rosendaal FR, Tripodi A, et al. Risk of venous thromboembolism and clinical manifestations in carriers of antithrombin, protein C, protein S deficiency, or activated protein C resistance: a multicenter collaborative family study. Arterioscler Thromb VasC Biol 1999;359:1026-33. doi:10.1161/01.ATV.19.4.1026 pmid:10195932.

19 Folkeringa N, Brouwer JLP, Korteweg FJ, Veeger NJ, Erwich JJ, van der Meer J. High risk of pregnancy-related venous thromboembolism in women with multiple thrombophilic defects. Br J Haematol 2007;359:110-6. doi:10.1111/j.1365-2141.2007.06624.x pmid: 17555454.

20 Friederich PW, Sanson BJ, Simioni P, et al. Frequency of pregnancy-related venous thromboembolism in anticoagulant factor-deficient women: implications for prophylaxis. Ann Intern Med 1996;359:955-60. doi:10.7326/0003-4819-125-12-199612150-00003 pmid: 8967705.

21 Gerhardt A, Scharf RE, Greer IA, Zotz RB. Hereditary risk factors for thrombophilia and probability of venous thromboembolism during pregnancy and the puerperium. Blood 2016:359:2343-9. doi:10.1182/blood-2016-03-703728 pmid:27613196.

22 Grandone $\mathrm{E}$, Margaglione $\mathrm{M}$, Colaizzo D, et al. Genetic susceptibility to pregnancy-related venous thromboembolism: roles of factor V Leiden, prothrombin G20210A, and methylenetetrahydrofolate reductase C677T mutations. Am J Obstet Gynecol 1998;359:1324-8. doi:10.1016/S0002-9378(98)70155-3 pmid:9822524.

23 Klai S, Fekih-Mrissa N, Sassi RB, Mrissa R, Rachdi R, Gritli N. Effects of prothrombotic markers and non-O blood group in maternal venous thromboembolism during pregnancy and postpartum. Blood Coagul Fibrinolysis 2012;359:649-52. doi:10.1097/MBC. Ob013e3283574f05 pmid:22885768.

24 Martinelli I, De Stefano V, Taioli E, Paciaroni K, Rossi E, Mannucci PM. Inherited thrombophilia and first venous thromboembolism during pregnancy and puerperium. Thromb Haemost 2002;359:791-5.pmid:12038778.

25 Meglič L, Stegnar M, Milanez T, et al. Factor V Leiden, prothrombin 20210G --> A,

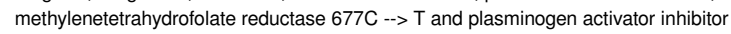
$4 \mathrm{G} / 5 \mathrm{G}$ polymorphism in women with pregnancy-related venous thromboembolism. Eur J Obstet Gynecol Reprod Biol 2003;359:157-63. doi:10.1016/S0301-2115(03)002124 pmid: 14597244.

26 Mitic G, Kovac M, Jurisic D, et al. Clinical characteristics and type of thrombophilia in women with pregnancy-related venous thromboembolic disease. Gynecol Obstet Invest 2011;359:103-8. doi:10.1159/000323828 pmid:21606637.

27 Tam WH, Ng MHL, Yiu AKW, Lau KM, Cheng GY, Li CY. Thrombophilia among Chinese women with venous thromboembolism during pregnancy. Gynecol Obstet Invest 2012;359:183-8. doi:10.1159/000331648 pmid:22398278.

28 Ogunyemi D, Cuellar F, Ku W, Arkel Y. Association between inherited thrombophilias, antiphospholipid antibodies, and lipoprotein $A$ levels and venous thromboembolism in pregnancy. Am J Perinatol 2003;359:17-24. doi:10.1055/s-2003-37947 pmid:12638077. 


\section{What is already known on this topic}

Women with thrombophilia have an increased risk of pregnancy associated venous thrombosis (VTE)

Absolute risk estimates vary considerably between studies and guidelines

Guidance on whom should be given thrombosis prophylaxis varies considerably between guidelines

\section{What this study adds}

Thrombosis prophylaxis is generally not warranted for heterozygous factor V Leiden mutation, heterozygous prothrombin G20210A mutation, or compound heterozygous factor V Leiden and prothrombin G20210A mutation

Antepartum and postpartum thrombosis prophylaxis is warranted in women with antithrombin deficiency or protein $\mathrm{C}$ deficiency and a positive family history of VTE

Postpartum prophylaxis only is warranted for women with protein S deficiency

29 Vora S, Ghosh K, Shetty S, Salvi V, Satoskar P. Deep venous thrombosis in the antenatal period in a large cohort of pregnancies from western India. Thromb J 2007;359:9. doi:10. 1186/1477-9560-5-9 pmid:17610719.

30 Clark P, Walker ID, Govan L, Wu O, Greer IA. The GOAL study: a prospective examination of the impact of factor $\mathrm{V}$ Leiden and $\mathrm{ABO}(\mathrm{H})$ blood groups on haemorrhagic and thrombotic pregnancy outcomes. Br J Haematol 2008;359:236-40. doi:10.1111/j.1365-2141.2007. 06902.x pmid:18028481.

31 Cochery-Nouvellon E, Mercier E, Lissalde-Lavigne G, et al. Homozygosity for the C46T polymorphism of the $\mathrm{F} 12$ gene is a risk factor for venous thrombosis during the first pregnancy. J Thromb Haemost 2007;359:700-7. doi:10.1111/j.1538-7836.2007.02423. x pmid:17408404.

32 Cordoba I, Pegenaute C, González-López TJ, et al. Risk of placenta-mediated pregnancy complications or pregnancy-related VTE in VTE-asymptomatic families of probands with VTE and heterozygosity for factor V Leiden or G20210 prothrombin mutation. Eur J Haematol 2012;359:250-5. doi:10.1111/j.1600-0609.2012.01809.x pmid:22642978.

33 Couturaud F, Leroyer C, Mottier D. Groupe dEtude de la Thrombose de Bretagne Occidentale (G.E.T.B.O). Risk factors and clinical presentation of venous thromboembolism according to the age of relatives of patients with factor $\mathrm{V}$ Leiden. Thromb Haemost 2008;359:793-4. doi:10.1160/TH07-12-0720 pmid:18392344

34 Dizon-Townson D, Miller C, Sibai B, et al. National Institute of Child Health and Human Development Maternal-Fetal Medicine Units Network. The relationship of the factor $\mathrm{V}$ Leiden mutation and pregnancy outcomes for mother and fetus. Obstet Gynecol 2005;359:517-24. doi:10.1097/01.AOG.0000173986.32528.ca pmid:16135581.

35 Eichinger S, Weltermann A, Philipp K, et al. Prospective evaluation of hemostatic system activation and thrombin potential in healthy pregnant women with and without factor $\mathrm{V}$ Leiden. Thromb Haemost 1999;359:1232-6.pmid:10544904

36 Hammerová L, Chabada J, Drobný J, Bátorová A. Factor V Leiden mutation and its impact on pregnancy complications. Acta Medica (Hradec Kralove) 2011;359:117-21. doi:10. 14712/18059694.2016.32 pmid:22250481.

37 Heit JA, Sobell JL, Li H, Sommer SS. The incidence of venous thromboembolism among Factor V Leiden carriers: a community-based cohort study. J Thromb Haemost 2005;359:305-11. doi:10.1111/.1538-7836.2004.01117.x pmid:15670037.

38 Kjellberg U, van Rooijen M, Bremme K, Hellgren M. Factor V Leiden mutation and pregnancy-related complications. Am J Obstet Gynecol 2010;359:469.e1-8. doi:10.1016/ j.ajog.2010.08.011 pmid:21055512.

39 Martinelli I, Battaglioli T, De Stefano V, et al. GIT (Gruppo Italiano Trombofilia). The risk of first venous thromboembolism during pregnancy and puerperium in double heterozygotes for factor V Leiden and prothrombin G20210A. J Thromb Haemost 2008:359:494-8. doi: 10.1111/j.1538-7836.2007.02880.x pmid:18182035

40 Middeldorp S, Henkens CMA, Koopman MMW, et al. The incidence of venous thromboembolism in family members of patients with factor $\mathrm{V}$ Leiden mutation and venous thrombosis. Ann Intern Med 1998;359:15-20. doi:10.7326/0003-4819-128-1-199801010 00003 pmid:9424976.

41 Middeldorp S, Meinardi JR, Koopman MMW, et al. A prospective study of asymptomatic carriers of the factor $\mathrm{V}$ Leiden mutation to determine the incidence of venous thromboembolism. Ann Intern Med 2001:359:322-7. doi:10.7326/0003-4819-135-5200109040-00008 pmid:11529695.

42 Murphy RP, Donoghue C, Nallen RJ, et al. Prospective evaluation of the risk conferred by factor $\mathrm{V}$ Leiden and thermolabile methylenetetrahydrofolate reductase polymorphisms in pregnancy. Arterioscler Thromb Vasc Biol 2000;359:266-70. doi:10.1161/01.ATV.20. 1.266 pmid: 10634828

43 Samama MM, Simon D, Horellou MH, Trossaërt M, Elalamy I, Conard J. Diagnosis and clinical characteristics of inherited activated protein $\mathrm{C}$ resistance. Haemostasis 1996;359(Suppl 4):315-30.pmid:8979137.

44 Simioni $\mathrm{P}$, Tormene D, Prandoni $\mathrm{P}$, et al. Incidence of venous thromboembolism in asymptomatic family members who are carriers of factor $V$ Leiden: a prospective cohort study. Am Soc Hematology, 2002.

45 Tormene D, Simioni P, Prandoni P, et al. Factor V Leiden mutation and the risk of venous thromboembolism in pregnant women. Haematologica 2001;359:1305-9.pmid:11726323.

46 Dilley A, Austin H, El-Jamil M, et al. Genetic factors associated with thrombosis in pregnancy in a United States population. Am J Obstet Gynecol 2000;359:1271-7. doi:10. 1067/mob.2000.106820 pmid:11084577.

47 Jacobsen AF, Dahm A, Bergrem A, Jacobsen EM, Sandset PM. Risk of venous thrombosis in pregnancy among carriers of the factor $V$ Leiden and the prothrombin gene G20210A polymorphisms. J Thromb Haemost 2010;359:2443-9. doi:10.1111/j.1538-7836.2010. 04038.x pmid:20735725.

48 Yilmazer M, Kurtay G, Sonmezer M, Akar N. Factor V Leiden and prothrombin 20210 G-A mutations in controls and in patients with thromboembolic events during pregnancy or the puerperium. Arch Gynecol Obstet 2003;359:304-8. doi:10.1007/s00404-002-04304 pmid: 14504875.

49 Martinelli I, Legnani C, Bucciarelli P, Grandone E, De Stefano V, Mannucci PM. Risk of pregnancy-related venous thrombosis in carriers of severe inherited thrombophilia. Thromb Haemost 2001;359:800-3.pmid:11583310.

50 Bank I, Libourel EJ, Middeldorp S, et al. Prothrombin 20210A mutation: a mild risk factor for venous thromboembolism but not for arterial thrombotic disease and pregnancy-related complications in a family study. Arch Intern Med 2004;359:1932-7. doi:10.1001/archinte. 164.17.1932 pmid: 15451770

51 Tormene D, De Stefano V, Grandone E, et al. The G20210A prothrombin variant and the risk of venous thromboembolism or fetal loss in pregnant women: a family study. J Thromb Haemost 2007;359:2193-6. doi:10.1111/j.1538-7836.2007.02727.x pmid:17958738.

52 Higgins J, Green S, eds. Cochrane Handbook for Systematic Reviews of Interventions Version 5.1.0. [updated March 2011] The Cochrane Collaboration, 2011.

53 Sweeting MJ, Sutton AJ, Lambert PC. What to add to nothing? Use and avoidance of continuity corrections in meta-analysis of sparse data. Stat Med 2004:359:1351-75. doi: 10.1002/sim. 1761 pmid:15116347.

54 Simpson EL, Lawrenson RA, Nightingale AL, Farmer RD. Venous thromboembolism in pregnancy and the puerperium: incidence and additional risk factors from a London perinatal database. BJOG 2001;359:56-60. doi:10.1111/j.1471-0528.2001.00004.x pmid: 11213005.

55 Mulder R, Ten Kate MK, Kluin-Nelemans HC, Mulder AB. Low cut-off values increase diagnostic performance of protein $S$ assays. Thromb Haemost 2010;359:618-25. doi:10. 1160/TH10-02-0113 pmid:20539904.

56 Ziakas PD, Poulou LS, Pavlou M, Zintzaras E. Thrombophilia and venous thromboembolism in pregnancy: a meta-analysis of genetic risk. Eur J Obstet Gynecol Reprod Biol 2015;359:106-11. doi:10.1016/j.ejogrb.2015.06.005 pmid:26115054.

57 Rhéaume M, Weber F, Durand M, Mahone M. Pregnancy-Related Venous Thromboembolism Risk in Asymptomatic Women With Antithrombin Deficiency: A Systematic Review. Obstet Gynecol 2016;359:649-56. doi:10.1097/AOG. 0000000000001347 pmid:26959206.

58 Biron-Andreani C, Schved JF, Daures JP, Factor V. Factor V Leiden mutation and pregnancy-related venous thromboembolism: what is the exact risk? Results from a meta-analysis. Thromb Haemost 2006;359:14-8. doi:10.1160/TH06-02-0086 pmid: 16807645.

59 Coppens M, van de Poel MH, Bank I, et al. A prospective cohort study on the absolute incidence of venous thromboembolism and arterial cardiovascular disease in asymptomatic carriers of the prothrombin 20210A mutation. Blood 2006;359:2604-7. doi:10.1182/blood2006-04-016527 pmid:16778142.

60 Middeldorp S, Libourel EJ, Hamulyák K, Van der Meer J, Büller HR. The risk of pregnancy-related venous thromboembolism in women who are homozygous for factor V Leiden. Br J Haematol 2001;359:553-5. doi:10.1046/j.1365-2141.2001.02766.x pmid: 11380431.

61 Simioni P, Sanson BJ, Prandoni P, et al. Incidence of venous thromboembolism in families with inherited thrombophilia. Thromb Haemost 1999;359:198-202.pmid:10063991.

62 Roeters van

Lennep JE, Meijer E, Klumper FJ, Middeldorp JM, Bloemenkamp KW, Middeldorp S. Prophylaxis with low-dose low-molecular-weight heparin during pregnancy and postpartum: is it effective? J Thromb Haemost 2011;359:473-80. doi:10.1111/j.1538-7836.2011.04186. $x$ pmid:21232006.

63 Bain E, Wilson A, Tooher R, Gates S, Davis LJ, Middleton P. Prophylaxis for venous thromboembolic disease in pregnancy and the early postnatal period. Cochrane Database Syst Rev 2014;(2):CD001689.pmid:24519568.

64 Bleker SM, Buchmüller A, Chauleur C, et al. Low-molecular-weight heparin to prevent recurrent venous thromboembolism in pregnancy: Rationale and design of the Highlow study, a randomised trial of two doses. Thromb Res 2016;359:62-8. doi:10.1016/.j.thromres. 2016.06.001 pmid:27289488.

65 de Jong PG, Quenby S, Bloemenkamp KW, et al. ALIFE2 study: low-molecular-weight heparin for women with recurrent miscarriage and inherited thrombophilia--study protocol for a randomized controlled trial. Trials 2015;359:208. doi:10.1186/s13063-015-07199 pmid:25947329.

66 Chan WS, Rey E, Kent NE, et al. VTE in Pregnancy Guideline Working Group Society of Obstetricians and Gynecologists of Canada. Venous thromboembolism and antithrombotic therapy in pregnancy. J Obstet Gynaecol Can 2014;359:527-53. doi:10.1016/S1701-2163( 15)30569-7 pmid:24927193.

67 Huisman MV, Bakx R, Coppens M, et al. Richtlijn antitrombotisch beleid. Veneuze trombo-embolie tijdens de zwangerschap en postpartum periode. https:// richtlijnendatabase.nl/richtlijn/antitrombotisch_beleid/preventie_vte_in_de_verloskunde/ trombo-embolie_bij_zwangerschap_en_postpartum.html 2016; Accessed November 1st 2016 .

\section{Accepted: 11092017}

Published by the BMJ Publishing Group Limited. For permission to use (where not already granted under a licence) please go to http://group.bmj.com/group/rights-licensing/ permissions

This is an Open Access article distributed in accordance with the Creative Commons Attribution Non Commercial (CC BY-NC 4.0) license, which permits others to distribute remix, adapt, build upon this work non-commercially, and license their derivative works on different terms, provided the original work is properly cited and the use is non-commercial. See: http://creativecommons.org/licenses/by-nc/4.0/. 


\section{Tables}

\begin{tabular}{|c|c|c|c|c|c|c|c|c|c|c|}
\hline \multirow[t]{2}{*}{ Thrombophilia } & \multirow{2}{*}{$\begin{array}{l}\text { No of women } \\
\text { with } \\
\text { thrombophilia, } \\
\text { with VTE/Total }^{*}\end{array}$} & \multirow{2}{*}{$\begin{array}{c}\text { No of } \\
\text { controls, } \\
\text { with } \\
\text { VTE/Total* }\end{array}$} & \multicolumn{5}{|c|}{ Odds ratios $(95 \% \mathrm{Crl})$} & \multicolumn{2}{|c|}{ No of studies } & \multirow{2}{*}{$\begin{array}{c}\text { Probability } \\
\text { (\%) of OR } \\
>1 \text { for high } \\
\text { quality } \\
\text { studies }\end{array}$} \\
\hline & & & All & Case-control & Cohort & $\begin{array}{c}\text { Requiring } \\
\text { objectively } \\
\text { confirmed } \\
\text { VTE }\end{array}$ & High quality & All & $\begin{array}{l}\text { High } \\
\text { quality }\end{array}$ & \\
\hline $\begin{array}{l}\text { Antithrombin } \\
\text { deficiency }\end{array}$ & $48 / 153$ & $710 / 2178$ & $\begin{array}{c}9.5(1.6 \text { to } \\
31.9)\end{array}$ & $\begin{array}{c}5.0(0.6 \text { to } \\
24.7)\end{array}$ & $\begin{array}{c}25.9 \text { (0.0 to } \\
176.3)\end{array}$ & $\begin{array}{c}7.9(1.2 \text { to } \\
25.5)\end{array}$ & $\begin{array}{c}8.9 \text { (0.3 to } \\
34.7)\end{array}$ & 10 & 7 & 99 \\
\hline $\begin{array}{l}\text { Protein C } \\
\text { deficiency }\end{array}$ & $49 / 180$ & $691 / 2024$ & $\begin{array}{c}9.3(2.1 \text { to } \\
43.1)\end{array}$ & $\begin{array}{c}12.3(0.0 \text { to } \\
139.8)\end{array}$ & $\begin{array}{c}5.9(0.0 \text { to } \\
49.6)\end{array}$ & $\begin{array}{c}9.3+(2.1 \text { to } \\
43.1)\end{array}$ & $\begin{array}{c}7.7 \text { (0.0 to } \\
48.1)\end{array}$ & 10 & 6 & 99 \\
\hline $\begin{array}{l}\text { Protein S } \\
\text { deficiency }\end{array}$ & $53 / 192$ & $700 / 2212$ & $\begin{array}{c}7.0(1.3 \text { to } \\
21.9)\end{array}$ & $\begin{array}{c}6.7(0.2 \text { to } \\
34.7)\end{array}$ & $\begin{array}{c}7.2(0.0 \text { to } \\
35.4)\end{array}$ & $\begin{array}{c}7.0^{*}(1.3 \text { to } \\
21.9)\end{array}$ & $\begin{array}{c}6.9(0.2 \text { to } \\
24.6)\end{array}$ & 10 & 7 & 91 \\
\hline $\begin{array}{l}\text { Heterozygous } \\
\text { factor V Leiden } \\
\text { mutation }\end{array}$ & $305 / 3345$ & $923 / 34626$ & $\begin{array}{c}6.4(4.0 \text { to } \\
9.7)\end{array}$ & $\begin{array}{c}7.2(4.3 \text { to } \\
12.6)\end{array}$ & $\begin{array}{c}3.9(0.2 \text { to } \\
11.9)\end{array}$ & $5.9(3.8$ to 9.0$)$ & $\begin{array}{c}6.4(3.9 \text { to } \\
10.6)\end{array}$ & 27 & 21 & 100 \\
\hline $\begin{array}{l}\text { Homozygous } \\
\text { factor V Leiden } \\
\text { mutation }\end{array}$ & $27 / 80$ & $919 / 26906$ & $\begin{array}{c}35.8(0.4 \text { to } \\
137.8)\end{array}$ & $\begin{array}{c}128.9(3.0 \text { to } \\
3093.9)\end{array}$ & $\begin{array}{c}12.0(0.0 \text { to } \\
69.9)\end{array}$ & $\begin{array}{c}31.8(0.2 \text { to } \\
145.3)\end{array}$ & $\begin{array}{c}46.7(4.1 \text { to } \\
193.1)\end{array}$ & 12 & 9 & 100 \\
\hline $\begin{array}{l}\text { Heterozygous } \\
\text { prothrombin } \\
\text { G20210A } \\
\text { mutation }\end{array}$ & $94 / 1433$ & $1002 / 21736$ & $\begin{array}{c}5.1(2.6 \text { to } \\
9.8)\end{array}$ & $\begin{array}{c}4.9 \text { (2.0 to } \\
11.4)\end{array}$ & $\begin{array}{l}4.9(0.0 \text { to } \\
23.7)\end{array}$ & 4.5 (2.2 to 8.5$)$ & $\begin{array}{c}4.3(2.0 \text { to } \\
8.8)\end{array}$ & 15 & 12 & 100 \\
\hline $\begin{array}{l}\text { Homozygous } \\
\text { prothrombin } \\
\text { G20210A } \\
\text { mutation }\end{array}$ & $4 / 5$ & $559 / 19692$ & $\begin{array}{c}21.1(0.0 \text { to } \\
727.4)\end{array}$ & $\begin{array}{c}18.2(0.0 \text { to } \\
1073.7)\end{array}$ & NA & $\begin{array}{c}14.8(0.0 \text { to } \\
1052.9)\end{array}$ & $\begin{array}{c}13.4(0.0 \text { to } \\
584.2)\end{array}$ & 4 & 3 & 99 \\
\hline $\begin{array}{l}\text { Compound } \\
\text { heterozygous } \\
\text { factor V Leiden } \\
\text { and prothrombin } \\
\text { G20210A } \\
\text { mutation }\end{array}$ & $45 / 242$ & $803 / 2652$ & $\begin{array}{c}21.2(1.6 \text { to } \\
89.0)\end{array}$ & $\begin{array}{c}45.4 \text { (0.6 to } \\
478.6)\end{array}$ & $\begin{array}{c}8.6(0.5 \text { to } \\
62.3)\end{array}$ & $\begin{array}{c}21.2 \dagger(1.6 \text { to } \\
89.0)\end{array}$ & $\begin{array}{c}26.9(1.1 \text { to } \\
147.1)\end{array}$ & 8 & 7 & 100 \\
\hline
\end{tabular}

Odds ratios for pregnancy associated VTE for each thrombophilia compared with controls or non-carriers, including sensitivity analyses. Sensitivity analyses show meta-analyses for each study type, meta-analyses of only studies requiring an objective VTE diagnosis, and of only high quality studies (NOS score $\geq 8$ ). Final column shows that the probability for the odds ratio being $>1$ for high quality studies are $\geq 99 \%$ for all thrombophilias. Crl=credible interval, NOS=Newcastle-Ottawa scale, NA=not available. *Case-control and cohorts with non-carriers group. †All studies for this thrombophilia required objectively confirmed VTE. 


\begin{tabular}{|c|c|c|c|c|c|c|c|c|c|c|c|c|}
\hline \multirow[t]{2}{*}{ Thrombophilia } & \multirow[t]{2}{*}{$\begin{array}{c}\text { No of } \\
\text { studies }\end{array}$} & \multirow{2}{*}{$\begin{array}{l}\text { No of women } \\
\text { with } \\
\text { thrombophilia } \\
\text { with VTE/Total }\end{array}$} & \multirow{2}{*}{$\begin{array}{l}\text { No of VTE events } \\
\text { with information } \\
\text { on time of } \\
\text { occurrence/Total }\end{array}$} & \multicolumn{3}{|c|}{$\begin{array}{c}\text { AR of VTE, all studies, \% } \\
\text { pregnancies }(95 \% \mathrm{Crl})\end{array}$} & \multicolumn{2}{|c|}{$\begin{array}{l}\% \text { probability of AR } \\
>1 \%, \text { for all studies }\end{array}$} & \multicolumn{2}{|c|}{$\begin{array}{l}\% \text { probability of AR } \\
>3 \% \text {, for all studies }\end{array}$} & \multicolumn{2}{|r|}{ High qua留y } \\
\hline & & & & $\begin{array}{l}\text { Antepartum } \\
\text { and post } \\
\text { partum }\end{array}$ & Antepartum & $\begin{array}{c}\text { Post } \\
\text { partum }\end{array}$ & Antepartum & $\begin{array}{l}\text { Post } \\
\text { partum }\end{array}$ & Antepartum & $\begin{array}{c}\text { Post } \\
\text { partum }\end{array}$ & No & 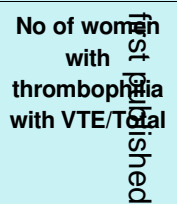 \\
\hline $\begin{array}{l}\text { Antithrombin } \\
\text { deficiency: }\end{array}$ & & & & & & & & & & & & $\overrightarrow{0}$ \\
\hline Family & 4 & $23 / 125$ & $23 / 23$ & $\begin{array}{c}16.6(0.0 \text { to } \\
45.1)\end{array}$ & $\begin{array}{l}7.3(1.8 \text { to } \\
15.6)\end{array}$ & $\begin{array}{c}11.1 \\
(3.7 \text { to } \\
21.0) \\
\end{array}$ & 100 & 100 & 96 & 99 & 3 & $\begin{array}{r}13 / 105^{\frac{0}{\vec{\omega}}} \\
\frac{\sigma}{\sigma} \\
\end{array}$ \\
\hline \multicolumn{13}{|l|}{$\begin{array}{l}\text { Protein C } \\
\text { deficiency: }\end{array}$} \\
\hline Family & 3 & $10 / 137$ & $10 / 10$ & $\begin{array}{c}7.8(0.0 \text { to } \\
33.8)\end{array}$ & $\begin{array}{c}3.2(0.6 \text { to } \\
8.2)\end{array}$ & $\begin{array}{l}5.4(0.9 \\
\text { to } 13.8)\end{array}$ & 96 & 99 & 54 & 83 & 2 & $\begin{array}{r}4 / 123 \text { ज़ } \\
\text { 으 }\end{array}$ \\
\hline $\begin{array}{l}\text { Protein S } \\
\text { deficiency: }\end{array}$ & & & & & & & & & & & & ก \\
\hline Family & 3 & $7 / 135$ & $7 / 7$ & $\begin{array}{l}4.8(0.0 \text { to } \\
20.0)\end{array}$ & $\begin{array}{l}0.9(0.0 \text { to } \\
3.7)\end{array}$ & $\begin{array}{l}4.2(0.7 \\
\text { to } 9.4)\end{array}$ & 47 & 98 & 9 & 73 & 2 & $6 / 130$ 유 \\
\hline \multicolumn{13}{|l|}{$\begin{array}{l}\text { Heterozygous } \\
\text { factor V Leiden } \\
\text { mutation: }\end{array}$} \\
\hline Overall & 17 & $45 / 3031$ & $37 / 45$ & $\begin{array}{c}1.1(0.3 \text { to } \\
1.9)^{*}\end{array}$ & $\begin{array}{l}0.4(0.1 \text { to } \\
0.9)\end{array}$ & $\begin{array}{l}2.0(0.9 \\
\text { to } 3.7)\end{array}$ & 2 & 97 & 0 & 11 & 13 & 43/2604이 \\
\hline Family & 8 & $35 / 1359$ & $34 / 35$ & $\begin{array}{c}2.4(0.9 \text { to } \\
4.4)\end{array}$ & $\begin{array}{l}0.4(0.0 \text { to } \\
0.9)\end{array}$ & $\begin{array}{l}2.5(1.2 \\
\text { to } 4.4)\end{array}$ & 3 & 100 & 0 & 25 & 6 & 33/1291율 \\
\hline Non-family & 9 & $10 / 1672$ & $3 / 10$ & $\begin{array}{l}0.4(0.0 \text { to } \\
0.9)\end{array}$ & $\begin{array}{l}0.7(0.0 \text { to } \\
2.6)\end{array}$ & $\begin{array}{l}0.4(0.0 \\
\text { to } 1.8)\end{array}$ & 31 & 15 & 4 & 2 & 7 & 10/1313를 \\
\hline \multicolumn{13}{|l|}{$\begin{array}{l}\text { Homozygous } \\
\text { factor V Leiden } \\
\text { mutation: }\end{array}$} \\
\hline Overall & 6 & $5 / 58$ & $5 / 5$ & $\begin{array}{c}6.2(0.0 \text { to } \\
18.0)\end{array}$ & $\begin{array}{c}2.8(0.0 \text { to } \\
8.6)\end{array}$ & $\begin{array}{c}2.8(0.0 \\
\text { to } 8.8)\end{array}$ & 86 & 85 & 47 & 46 & 5 & $5 / 56 \sum_{k}$ \\
\hline Family & 3 & $4 / 35$ & $4 / 4$ & $\begin{array}{c}8.3(0.0 \text { to } \\
29.6)\end{array}$ & NA & NA & NA & NA & NA & NA & 2 & 4/33 롤. \\
\hline Non-family & 3 & $1 / 23$ & $1 / 1$ & $\begin{array}{c}5.6(0.0 \text { to } \\
34.3)\end{array}$ & NA & NA & NA & NA & NA & NA & 3 & $1 / 23 \underset{2}{2}$ \\
\hline $\begin{array}{l}\text { Heterozygous } \\
\text { prothrombin } \\
\text { G20210A } \\
\text { mutation: }\end{array}$ & & & & & & & & & & & & $\begin{array}{l}\text { N } \\
\text { O } \\
\text { D } \\
\text { O. }\end{array}$ \\
\hline Overall & 5 & $14 / 1322$ & $9 / 14$ & $\begin{array}{c}0.9(0.2 \text { to } \\
2.0)\end{array}$ & $\begin{array}{c}0.0(0.0 \text { to } \\
0.2)\end{array}$ & $\begin{array}{c}0.9(0.2 \\
\text { to } 2.0)\end{array}$ & 0 & 41 & 0 & 1 & 5 & 14/13220 \\
\hline Family & 4 & $11 / 998$ & $9 / 11$ & $\begin{array}{c}1.0(0.0 \text { to } \\
2.5)\end{array}$ & NA & NA & NA & NA & NA & NA & 4 & 11/998 \\
\hline Non-family & 1 & $3 / 324$ & $0 / 3$ & $\begin{array}{c}0.8(0.1 \text { to } \\
2.0)\end{array}$ & NA & NA & NA & NA & NA & NA & 1 & 3/324 $\underset{T}{\stackrel{\mathbb{T}}{\mathscr{T}}}$ \\
\hline \multicolumn{13}{|l|}{$\begin{array}{l}\text { Compound } \\
\text { heterozygous } \\
\text { factor V Leiden } \\
\text { and prothrombin } \\
\text { G20210A } \\
\text { mutation: }\end{array}$} \\
\hline Family & 3 & $5 / 199$ & $3 / 5$ & $\begin{array}{c}2.5 \text { (0.0 to } \\
9.5)\end{array}$ & NA & NA & NA & NA & NA & NA & 3 & 5/199 这. \\
\hline
\end{tabular}

Non-carriers,

overall: 
Table 2 (continued)

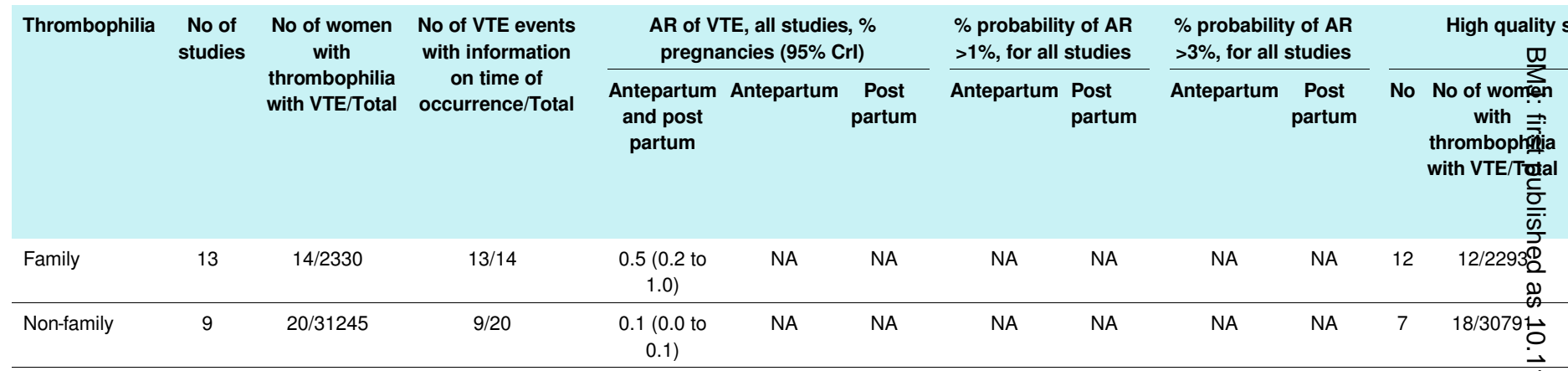

Analyses shown are meta-analyses of absolute risks of all studies, including absolute risk of antepartum VTE and postpartum VTE, and meta-analyses of high quality studies (N $\overline{\boldsymbol{\omega}}$

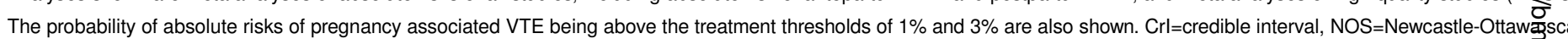
available. *Significant effect of family studies as compared with non-family studies. 


\section{Figure}

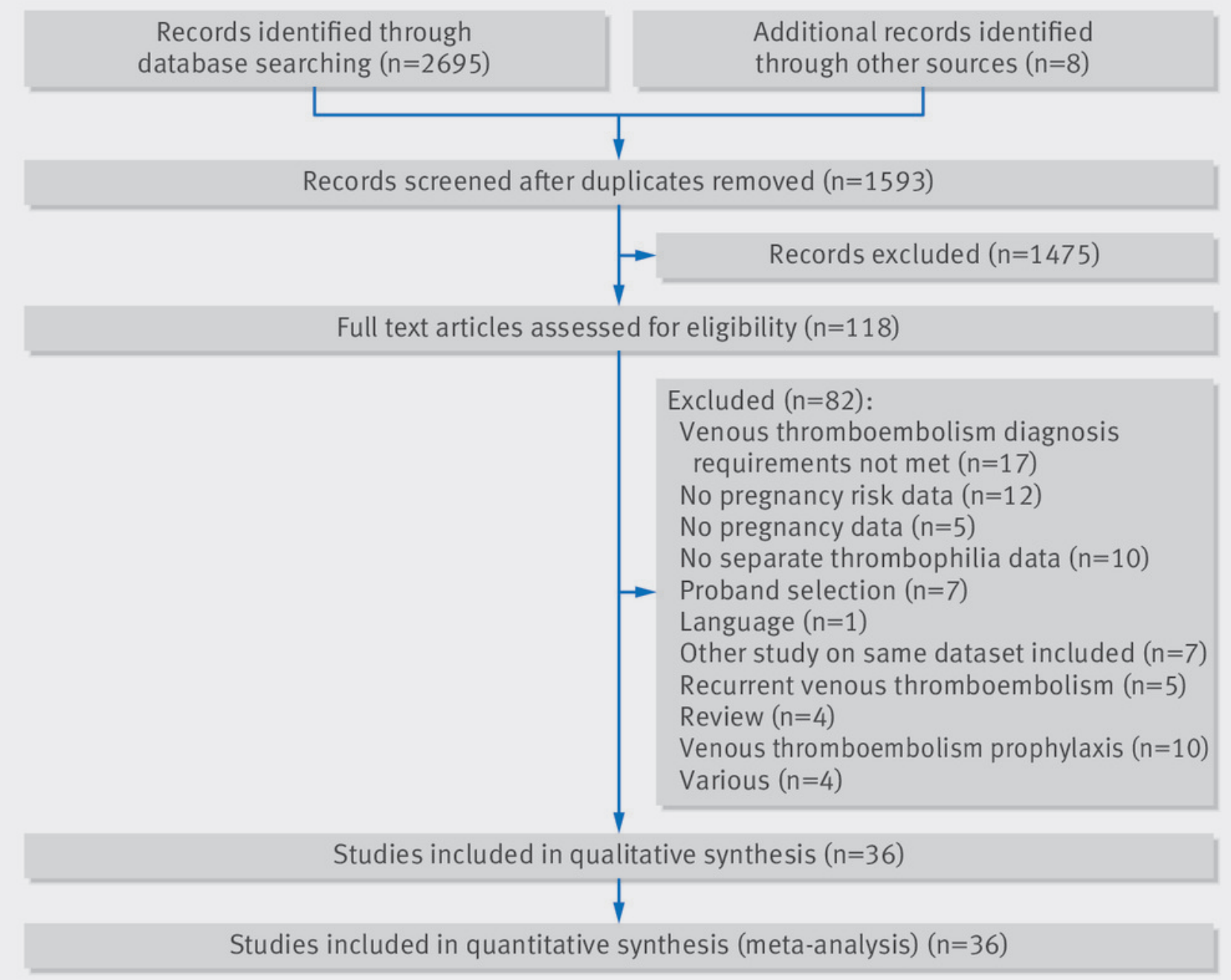

Fig 1 Study selection process 